\title{
Airbnb Branding: Heritage as a Branding Element in the Sharing Economy
}

\author{
Alvaro Fierro ${ }^{1, *}$ and Ibon Aranburu 2 (D) \\ 1 Faculty of Economics and Business, University of the Basque Country UPV/EHU, \\ Avda Lehendakari Agirre 83, 48015 Bilbao, Spain \\ 2 School of Engineering, University of the Basque Country UPV/EHU, Alameda de Urquijo, \\ 48013 Bilbao, Spain; ibon.aranburu@ehu.eus \\ * Correspondence: afierro001@ikasle.ehu.es; Tel.: +34-652-72-39-48
}

Received: 30 November 2018; Accepted: 21 December 2018; Published: 23 December 2018

check for updates

\begin{abstract}
The cultural heritage of cities has been proven to be a generator of economic activity and a singular place branding/marketing tool for territories. In addition, in recent times, there has been a boom in the collaborative economy in urban destinations, epitomized by accommodation companies, such as Airbnb. The main objective of this article was to analyze how cultural heritage adds value to the collaborative economy. To this end, a method was proposed that analyzed Airbnb host descriptions, detecting the cultural and heritage goods mentioned, therein, which are used as marketing elements. From these cultural assets, various econometric models were generated that aimed to assess the number of guest reviews, which were used as a proxy for the number of guests. To evaluate this method, a case study was developed in the city of Bilbao. In view of the results, it can be concluded that cultural heritage and spatial location positively influence the activity of the collaborative economy, increasing the number of guests and their economic value.
\end{abstract}

Keywords: cultural tourism; heritage; sharing economy; place branding; Airbnb; multivariate analysis

\section{Introduction}

In recent years, the cultural dimension has become increasingly important in the economic performance of cities. This trend is also present in tourism and urban cultural destinations. The first approaches to cultural/heritage tourism were based on places and monuments as cultural attractions [1]. Gradually, a broader vision emerged that included performing arts [2], handicrafts, cultural events, architecture and design, and most recently, creative activities [3,4] and intangible heritage $[5,6]$.

Much of the success of cultural destinations lies in the positive economic impact they generate [7-9] and their sustainable contribution to local development [10-13]. This fact is reflected in aspects such as, the generation of direct economic activity, the maintenance and conservation of heritage, the development of new cultural resources, the creation of a creative image of the city, etc. The importance of culture as an engine for urban tourism can be seen from the fact that it is one of the most important factors taken into consideration, when choosing a destination [14].

At the time of choosing and consuming the destination, tourists consume not only spaces but also images of the city [15]. Related to the image of a city, it should be taken into account that cities promote themselves by means of cultural and heritage goods. Therefore, cultural heritage also serves as a branding and differentiation tool for cities [16-18]. The importance of the image for the consumer or user of the place is what connects city branding to cultural geography [17].

In addition, some authors $[19,20]$ have suggested that tourist preferences are influenced by the heritage and cultural elements in destinations, despite the existence of other significant attributes that 
are unrelated to these. This influence of cultural elements can occur even before the visit, through the image created by tourism destination websites [21].

Other effects of cultural heritage analyzed in the literature, are those related to the residential property values [22]. According to Franco and Macdonald, the effects of cultural heritage amenities or ensembles of the economic value of a location, not only differ across space but also across heritage types (historic buildings, monuments, and other heritage assets).

Taking into account that nowadays an important part of the tourist experience takes place on the Internet (before, during, and after the trip), social media analytics and online platforms analytics have become significant tools for understanding tourist behavior and the branding creation process of destinations [23]. Thus, some studies [24,25] have examined major online review platforms (TripAdvisor, Expedia, and Yelp) to identify opportunities and evaluate their impact on the hospitality and tourism sector. For this purpose, some keywords and composite words related to cultural heritage have been identified. Similarly, Marine-Roig [26] analyzed online travel reviews as presented in search engines, emphasizing the cognitive, spatial, temporal, evaluative, and affective dimensions related to the destination image. Other authors have analyzed the influence of cultural tourism on Twitter [27], extracting, for example, trending topics that can be related semantically with the content of a cultural institute and examining how a venue can benefit by exploiting these matches.

At present, in parallel with the growth of heritage tourism, a boom in the sharing economy is taking place in urban destinations, which is having a huge impact on Hospitality and Tourism. In recent years, there have been an increasing number of academic studies concerning the impact on the phenomenon of the so-called collaborative economy or platform economy [28], both as a phenomenon of transformation $[29,30]$ and in relation to its legal aspects [31,32]. Specifically, Airbnb is generating considerable academic interest, with regard to various issues within the scope of this activity, both from a territorial [33] and an economic point of view [34,35]. However, there are hardly any articles that have studied the real-time consequences of medium-sized cities [36], such as the case of Bilbao [37], which, supported by a successful place branding strategy, is experiencing a growth in tourism, which in turn has complemented the increase in traditional as well as "collaborative" accommodation.

To date, little attention has been paid to analyzing how cultural heritage influences the collaborative economy or to studying the branding role of cultural heritage in the collaborative economy. Therefore, this work aimed to fill this gap by proposing a method to evaluate the role of cultural heritage on the sharing economy. For this purpose, a case study was performed in the city of Bilbao.

\section{Literature Review}

\subsection{The Role of Place/Heritage Branding in the Cities}

In today's world, cities compete with each other to attract investment and tourists, by virtue of their brand image [38]. Branding, mainly developed from marketing strategies, is increasingly used to market and promote cities, in a similar way to products. This competition among cities is a result of globalization [39]. Under these terms, places are products whose identities and values must be designed and marketed [40]. When discussing the image of a city from the branding perspective, it should be first noted that, nowadays, many cities attempt to promote themselves through the aid of iconic artefacts [41]. In addition, place branding involves factors, such as infrastructure/facilities, heritage and cultural attractions, services, media, and relationships, among others [23,42]. Thus, it can be said that there are three main approaches to promoting cities-cultural mega events, heritage restoration and promotion, and the construction of iconic buildings [39,43].

Among the studies reviewed, there have been a number of authors who have highlighted the attraction of tourists as the main task of city branding. Szondi [44] argues that when developing the brand of a country or city, the attraction of tourists must be the main focus of their efforts. For example, countries such as Costa Rica, Moldova [45], Turkey [46], and Spain [47] were subjected to brand 
changing processes, with the aim of promoting a positive image, oriented toward boosting tourism. However, city branding has different purposes and goes beyond tourist attraction.

\subsection{The Role of Heritage Branding in the Sharing Economy}

In recent years, a series of new concepts related to new forms of consumption and economic organization have gained significant importance, some of these concepts are collaborative consumption, the collaborative economy, and the sharing economy. The sharing economy is based on the interaction between two or more subjects through the use of digital platforms [48], which reduces transaction costs, in the case of Airbnb, between those who offer and those who buy accommodation. Schor et al. [49] also pointed out that consumers in the collaborative economy tend to be people with a high cultural level, which is a prevalent characteristic in urban destinations. In traditional online platforms, consumer reviews or rating scores are key factors with which to build and enhance trust between consumers and sellers. However, in sharing economy platforms, such as Airbnb, host ratings are particularly high and positive [50,51]. In this way, these rating scores are not valuable enough for decision-making, and guests depend on other information, such as host attributes [52]. For example, some researchers found that hosts' photos on Airbnb may affect guests' decisions more than other attributes [53]. Furthermore, in 21st century cities, there are numerous attractions distributed throughout the city, enabling hosts to have unique and greater opportunities to market their offer. Thus, the sharing economy is embracing culture and heritage in order to exhibit and promote its authenticity, a key factor when generating the trust and the satisfaction of guests [54,55]. Taking into account all of the above, this article focused on the assessment of the role of cultural heritage on the sharing economy.

This new socio-economic movement, which encompasses the concepts mentioned above, is gaining additional momentum, due to the juncture of several incipient social, cultural, and economic situations. In social media, users are no longer passive beings seeking and receiving information; instead, the logic of connectivity between peers-or $\mathrm{p} 2 \mathrm{p}-$ facilitates direct contact between users, without the need for intermediation. The rules of the game have changed, and social media has promoted the empowerment of consumers. According to the Spanish National Commission on Markets and Competition [56], the collaborative economy is a new economic model, based on the exchange of goods and services between individuals that are otherwise idle or underutilized, these assets are provided in exchange for some sort of compensation agreed upon between the parties. The change that is taking place, with regard to the consumption habits of individuals, is outstanding. This has translated into a substantial increase in collaborative economy platforms-usually within a digital framework - that only a few years ago reported residual activity. Regarding tourism, in the article "The Rise of the Sharing Economy: Estimating the Impact of Airbnb on the Hotel Industry" [35], a series of conclusions were drawn. By estimating regression models with fixed effects, in order to compare the Airbnb offer, over time, for the cities of Austin and Dallas (United States), it was concluded that there was a significant negative impact on hotels and that this impact was not heterogeneous. In fact, the most affected were the modest and standard establishments, whereas luxury establishments did not report significant alterations. Due to this impact, it was noticeable that hotels had taken competitive measures, such as lowering prices. In the case of Bilbao, however, it was found that the Airbnb platform had no detrimental effects on the operation of traditional hotels, due to the relatively small weight it still has in Bilbao [37].

\section{Case Study}

The case study was developed in the city of Bilbao (Basque Country, in Northern Spain) for three reasons. The first reason is that the city has been focused for several years on cultural tourism, as part of its branding strategy. Second, according to the latest reports published by Airbnb in 2018 (data from 2017), more than 90,000 visitors booked accommodation in Bilbao through Airbnb, while 913,006 visitors booked in hotels, during the same period [57]. This means that Airbnb's turnover (2017) in Bilbao represents almost $10 \%$ of the business of all hotels in Bilbao. It was highlighted in the 
report that Bilbao was positioned as the eighth most fashionable city, worldwide, in 2018, thanks to the wide range of cultural and gastronomic attractions on offer, as well as the possibility of being able to practice numerous sports and the opportunities to enjoy family tourism. The city of Bilbao, which has experienced a $234 \%$ increase in bookings, is the only Spanish city included in the List of World Destinations, and ranks second in Europe [58].

The third reason is because, according to the official data from the Tourism Office, Bilbao and the province of Bizkaia are currently enjoying their finest moment in this regard. The year 2017, was a record year for tourism in this province, with 1,461,117 registered entries in hotels and rural accommodations. This was 5.3\% higher than that in 2016, and clearly stands out, when compared to the $1 \%$ increase in the rest of the state. In addition, visits from foreign travelers increased by $12.7 \%$. This sector accounted for $6 \%$ of the Basque GDP.

In the case of Bilbao, and in relation to place branding theory, there was one fundamental factor in its economic development: The Guggenheim Museum. This flagship building stands as the result of a series of multiple coincidences, of which the most significant one is the search for liquidity on the part of the Guggenheim Foundation (New York), together with the fact that the city was looking for an emblematic urban artifact to symbolize the beginning of its regeneration process $[59,60]$. This has underpinned a consequent upswing in the positive perception of Bilbao [61,62], on behalf of both locals and foreigners, which has led to a rise in tourist activity. At the same time, the increase in trips has been crystallized, partly through the comments shared on online media and social networks.

In a first descriptive analysis, it can be seen how the distribution and characteristics of Airbnb vacation rentals are concentrated in the old part of Bilbao (see Figure 1), specifically in three neighborhoods (see Figure 2). Therefore, to first determine the distribution of Airbnb accommodation space in Bilbao, this study corroborated the spatial concentration in the neighborhoods mentioned above, thus, the mobility of the guests using the Airbnb platform in this area.

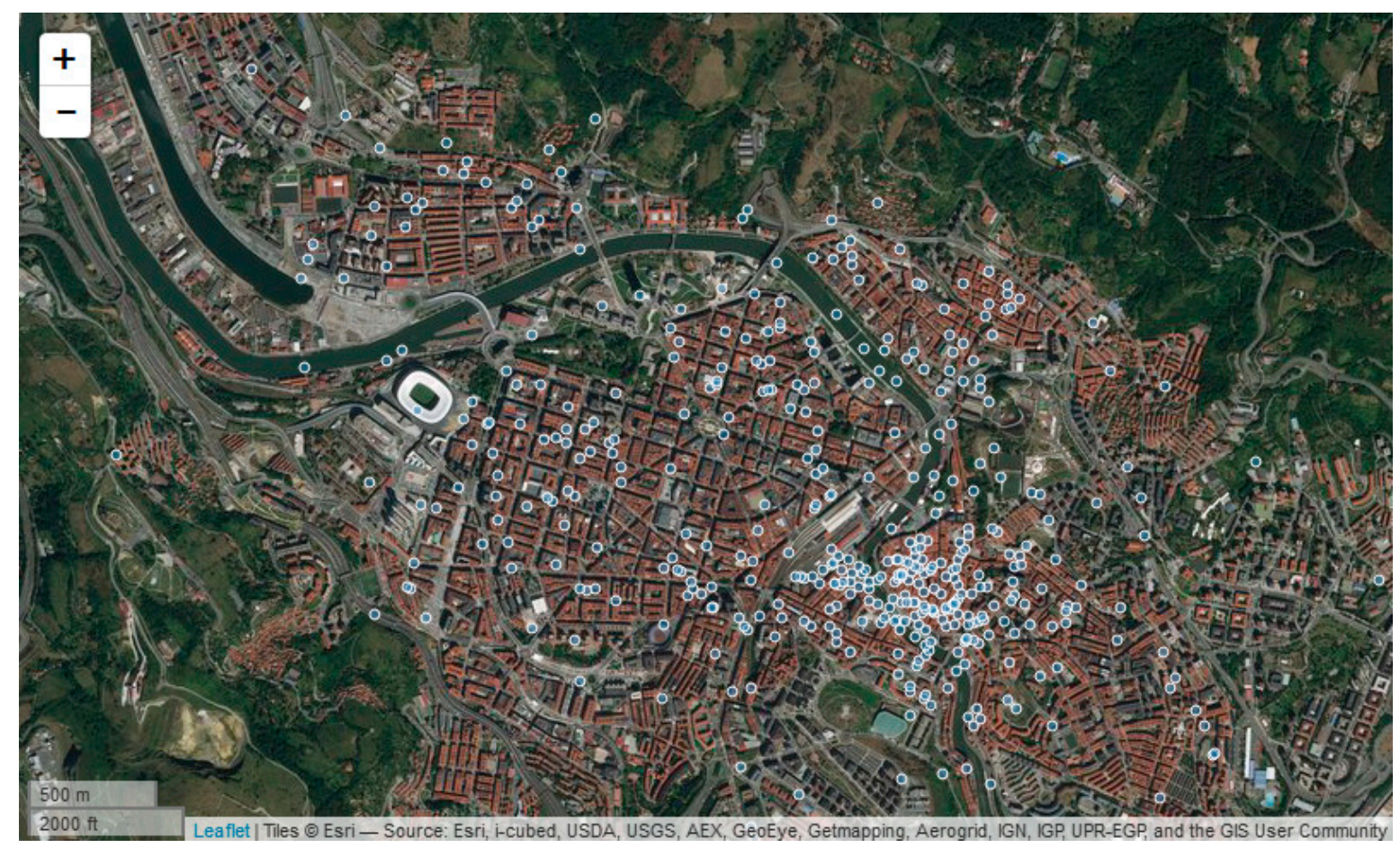

Figure 1. General view of the concentration of Airbnb accommodation in the city of Bilbao (Source: own elaboration).

It can also be seen in Figure 2 that the points of tourist interest (in red) that are named by the Bilbao administration, are not found within the areas of the highest density of Airbnb homes in Bilbao. 


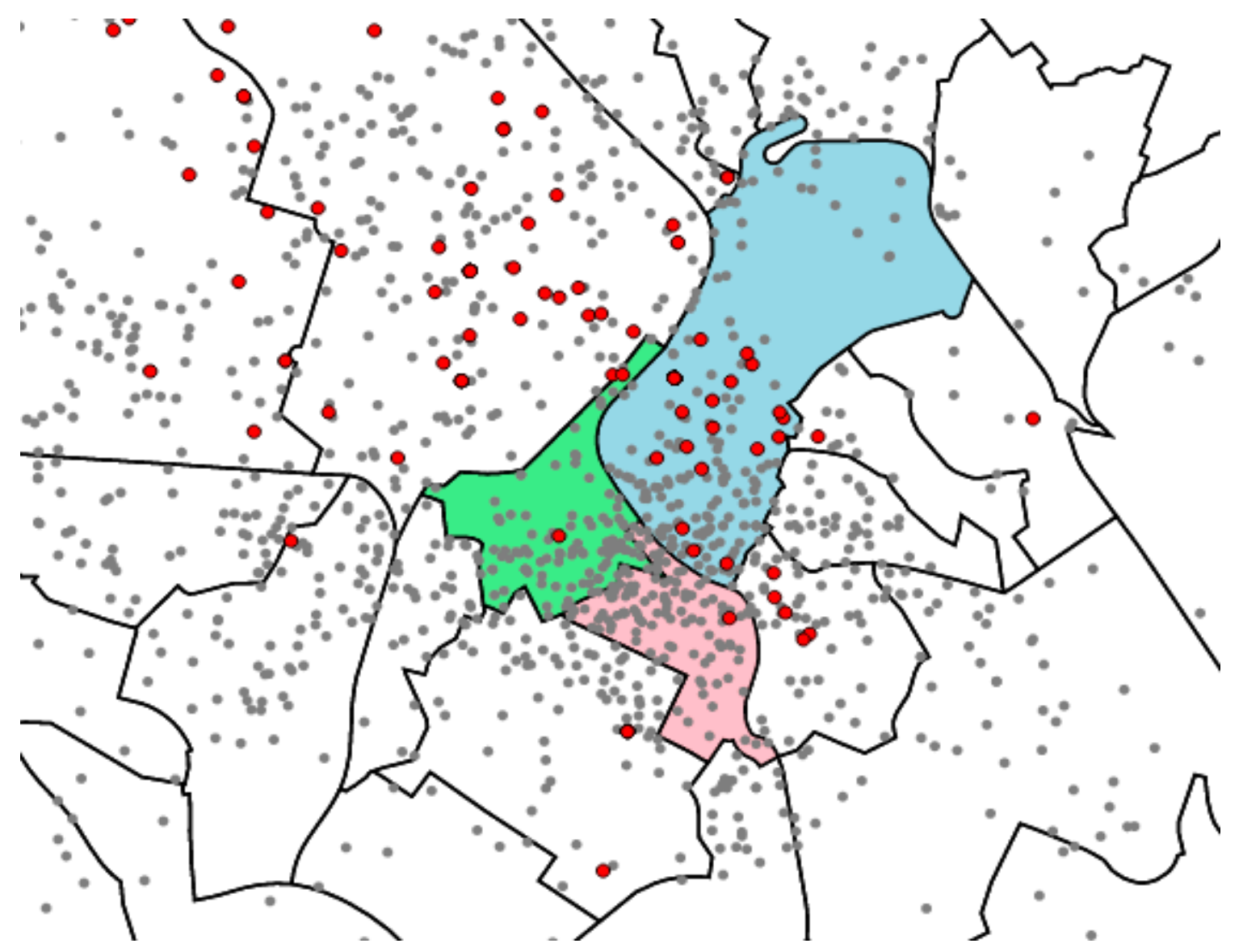

Figure 2. Concentration of Airbnb accommodation in the three neighborhoods of the old part of Bilbao. Blue: Casco Viejo/Old Town; Pink: Bilbao La Vieja; Green: San Francisco (Source: own elaboration).

In addition, some attributes of Airbnb accommodation are depicted in Table 1, in order to gain better insights into them. Thus, the following accommodation information is shown-the number of accommodations in Bilbao; the average number of reviews; the average price; the average rating; and the number of mentions of heritage elements. This information was divided into accommodations located in the Old Town and those not located in the Old Town (the rest of the accommodation).

Table 1. The characteristics of Airbnb accommodation in Bilbao (2017).

\begin{tabular}{cccc}
\hline Accommodation Characteristics & Whole Bilbao & Old Town & Rest of Bilbao \\
\hline No. of accommodation * & 318 & 145 & 173 \\
Average No.N. of Reviews & 50.64 & 39.14 & 60.75 \\
Average Price & 65 & 68.28 & 63.33 \\
Average Rating & 92.44 & 92.12 & 92.56 \\
No. of Mentions (Heritage Elements) & 1266 & 442 & 824 \\
\hline
\end{tabular}

${ }^{*}$ No. of accommodations with zipcode.

In Table 1, meaningful differences between the accommodations located in the Old Town and those that are not, can be seen. In this regard, it is worth mentioning that the average number of reviews and the number of heritage elements mentioned where accommodation is located in the Old Town, had significantly lower values.

Finally, as a starting hypothesis, the following questions arose, which is why we studied the role of the host in the descriptions of their accommodation: Do the tourists that visit Bilbao and stay in Airbnb accommodation continue to be attracted by the so-called "Guggenheim effect"? [62]. Or are there other elements—cultural, heritage, etc.-as described in the aforementioned Airbnb report, which draw 
visitors to Bilbao? The objective of this study was to provide satisfactory answers to these questions by means of empirical evidence, combining unstructured data through a multivariate regression analysis.

\section{Methods}

\subsection{Data Selection}

Next, the data used for the analysis were described. The data were collected from the descriptions of the accommodation made by the hosts and were presented on the platform. The heritage keywords were determined and their presence in the descriptions noted. Precisely 326 places in Greater Bilbao were analyzed from January to March of 2017. The heritage keywords were chosen because, in a first descriptive analysis, these elements were numerous and had more visibility, when compared with others. The next part of the study focused on three neighborhoods, after observing that the presence of Airbnb in the old quarter of Bilbao was higher, when compared with other areas of the municipality. Similarly, it was observed that the most famous heritage elements were concentrated in this zone. To this end, using a multivariate model, we tested whether the keywords found in the host description had positive effects on each accommodation, by collecting the number of reviews of each host. As previously mentioned, we did not have real data concerning the reservations, so we used the number of reviews as a proxy variable for booking accommodations. In other words, we studied whether cultural heritage and a specific location, positively influenced the activity of the collaborative economy and had a significant impact on the number of guests and its economic value. For this screening, the type of accommodation (single room, shared room, or a flat...) was not taken into account. This, and similar types of issues have been considered in other research papers, from the point of view of both the hosts and guests $[63,64]$.

The heritage information collected was used as the critical mass to provide content to the Airbnb data repository, developed by the Montera 34 organization [65], called Datahippo, which was started in order to democratize Airbnb information. This information has been developed in the same way as others, such as insideairbnb, AirDNA, or the Tom Slee database.

However, since these peer-to-peer tools ( $\mathrm{p} 2 \mathrm{p}$ ) have gained in popularity and given the protective nature of these companies when it comes to data sharing-which explains the appearance of different applications such as insideairbnb.com-it is difficult to estimate the number of visitors who choose to go to Bilbao on vacation, and the revenue they generate for the city and the surrounding areas. Thus, official sources within the tourism administration area of the city cannot accurately estimate how many tourists have stayed in places other than hotels, hostels, guest houses, and other regulated accommodation facilities. In order to advance toward more accurate assessments, the following research was taken as a reference case study: "The Impact of Tourism and the Sharing Economy Phenomenon in the Old Part of Bilbao (Spain): An Approximation through a Negative Binomial Distribution" [37]. In this research work, holiday rental offers on Airbnb, the profile of the visitors, as well as an estimate of the number of guests, were analyzed, taking the number of comments posted by guests on the platform after their stay, as a proxy variable.

Following the most recent update of this organization, the text description of the hosts in 2017 were used for this analysis. The design was based on a number of keywords that had a greater visibility, in terms of their connections with the heritage of Bilbao and with tourism, always from a positive point of view and a priori, assuming that the more positive mentions there were in the written comments, the greater the impact of the cultural brand of the territory. In consensus with the research team, the following keywords were set, in coherence with the current brand image of Bilbao:

- The Arriaga Theater: The oldest theater in Bilbao, opened in 1890 and named in honor of the Bilbao musician Juan Crisóstomo Arriaga, known as the Spanish Mozart.

- The River: This flows through and around the city, and in the industrial era was the most important in Northern Spain. 
- Santiago Cathedral: Bilbao Cathedral is dedicated to St. James the Apostle, the patron saint of Bilbao since 1643; built in the fifteenth century, in a Gothic style, although its tower and façade are neo-Gothic.

- Siete Calles / Seven Streets: One of the main leisure and shopping centers of Bilbao, located in the Old Town.

- Ribera Mercado/Ribera Market: Is a reference in terms of shopping for the whole of Biscay. One of its many merits is to have been recognized in 1990 as the most complete municipal food market by the Guinness Book of Records, at that time being the largest in terms of traders and stalls, and a covered market with the largest area in the whole of Europe.

- The Guggenheim Museum: The iconic artifact that put Bilbao on the world map.

- Pintxos/Pinchos: A typical Basque appetizer.

- Casco Viejo/Old Town: This is a large "open air" hospitality and shopping pedestrian area, where one can find a mixture of shops, bars, and historical heritage.

- Plaza Nueva/New Square: A monumental square in the neoclassical style built in 1821 . Each Sunday, the square provides space for a traditional flea market, where vintage books, coins, stamps, birds, and flowers are sold. The square is often used for folk performances, festivals, and concerts.

(Source: own elaboration) As seen in Figure 3, the most mentioned heritage element by the hosts was the Old Town, more than twice that of the other elements, such as the Guggenheim Museum, the river, or the Ribera Market. Next in the ranking appeared other heritage elements related to gastronomy (pintxos) and theater, and further down there were some historic buildings.

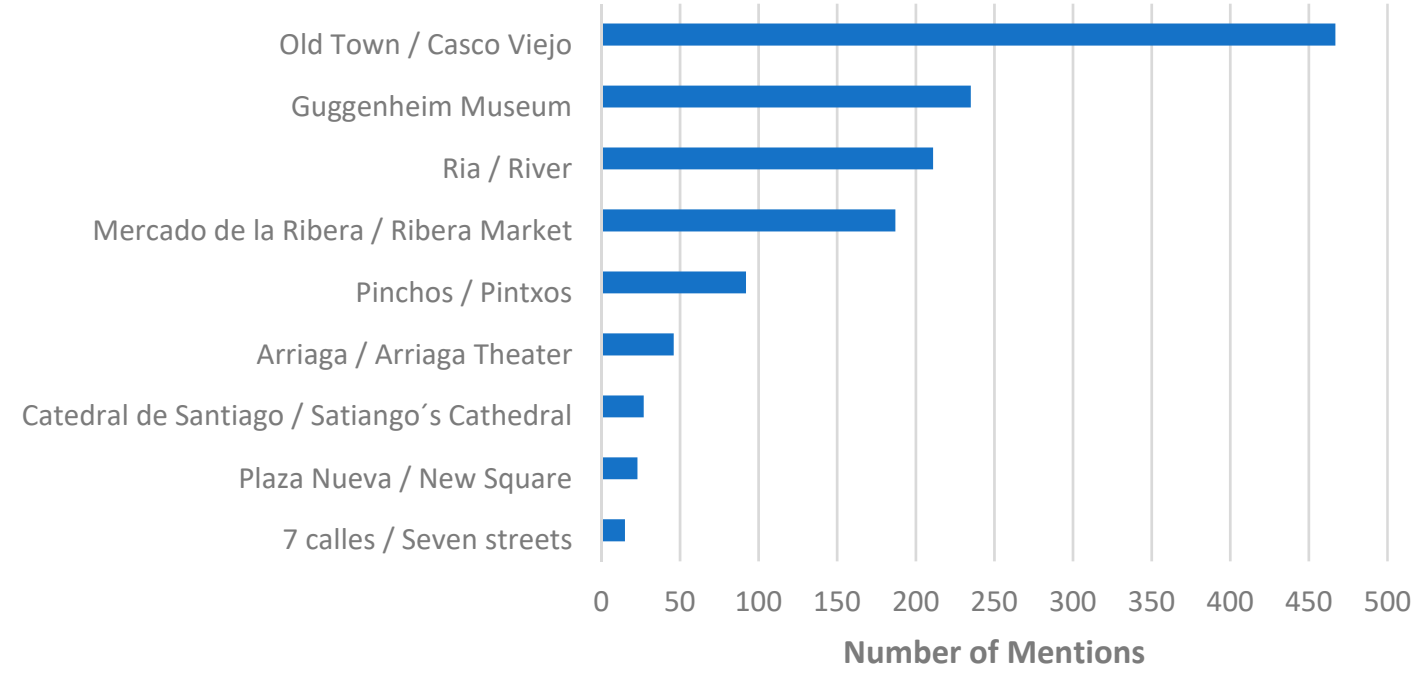

Figure 3. The ranking of heritage elements of Bilbao mentioned in the hosts' descriptions (Source: own elaboration).

Finally, the price of each accommodation and its location was included in the analysis. In this case, the examination was based on the zipcodes of each accommodation, in order to geolocate each one and detect if they were in the neighborhoods of the old part. Thus, in order to design the dummy variable Place, the postal codes of the zones, streets and sections annexed to the old part of the city were noted. Specifically, a value of 1 was given if the postal codes were 48003,48004, 48005, and 48006, and 0 otherwise.

\subsection{Econometric Methodology}

For the analysis of this data, first an ANOVA (plus Levene Test) analysis was performed to evaluate if the relationship between the location and the number of reviews was significant. ANOVA 
is mostly able to present the differences between the categories' means in the data [66]. In the event that the differences were significant, a regression analysis was performed to estimate the number of reviews.

Furthermore, to cross check the number of reviews and the heritage keywords, an ordinary least squares (OLS) cross-section method was employed to detect if any of the variables that were chosen as being representative of the cultural brand image of Bilbao, resisted statistical inference. OLS is a widely used method in regression analysis, mainly because it is intuitively attractive and mathematically simpler than the other alternatives [66]. Kendall and Stuart (1961), as quoted by Gujarati, claimed that a statistical link, however strong and however suggestive, could never establish a causal connection: the ideas of causality could come from beyond the statistics, ultimately, from some theory or social debate. Therefore, to check whether the causal inferences made were consistent with the available data, OLS was used. Based on certain assumptions, OLS has some statistical properties that makes it one of the most powerful and popular methods of regression analysis.

The purpose of linear regression analysis is to assess a model that seeks to explain the behavior of a variable (endogenous, explained, or dependent variable), which is denoted by $Y$, by using the values for a set of variables (explanatory, exogenous, or independent), which is denoted by $X 1, X 2, \ldots, X n$, in this case, the variable $Y$ or the dependent variable, which consists of the number of reviews per accommodation, as a proxy for the number of bookings, and therefore, of visitors. The $\mathrm{X}$ variables, on the other hand, consist of the number of mentions of the keywords in the title, summary, the space, and the description of the host's advertisement.

With this technique, and using the Gretl software, two econometric models were designed with and without the Guggenheim variable.

\section{Model 1}

$$
\Upsilon=B_{0}+B_{1} X_{1}+B_{2} X_{2}+B_{3} X_{4}+B_{5} X_{5}+B_{6} X_{6}+B_{7} X_{7}+B_{8} X_{8}+\varepsilon_{i}
$$

where

$\gamma_{t}$ is the number of reviews about each accommodation.

$X_{1} \quad$ is the number of mentions of the keyword "Pintxos" in the descriptions of each host.

$\mathrm{X}_{2}$ is the number of mentions of the keyword "Old Town" in the descriptions of each host.

$\mathrm{X}_{3}$ is the number of mentions of the keyword "Cathedral" in the descriptions of each host.

$\mathrm{X}_{4}$ is the number of mentions of the keyword "Guggenheim" in the descriptions of each host.

$X_{5}$ is the number of mentions of the keyword "River" in the descriptions of each host.

$\mathrm{X}_{6}$ is the number of mentions of the keyword "Ribera Market" in the descriptions of each host.

$\mathrm{X}_{7} \quad$ is the price of each accommodation.

$\mathrm{X}_{8} \quad$ is a dummy variable, which is 1 if it is situated in the old part of the city; otherwise it is 0 .

$\varepsilon_{\mathrm{i}} \quad$ a random disturbance.

Model 2 (excluding the Guggenheim)

$$
\Upsilon=B_{0}+B_{1} X_{1}+B_{2} X_{2}+B_{3} X_{4}+B_{5} X_{5}+B_{6} X_{6}+B_{7} X_{7}+\varepsilon_{i},
$$

where

$r_{t}$ is the number of reviews about each accommodation.

$X_{1} \quad$ is the number of mentions of the keyword "Pintxos" in the descriptions of each host.

$\mathrm{X}_{2}$ is the number of mentions of the keyword "Old Town" in the descriptions of each host.

$\mathrm{X}_{3}$ is the number of mentions of the keyword "Cathedral" in the descriptions of each host.

$\mathrm{X}_{4} \quad$ is the number of mentions of the keyword "River" in the descriptions of each host.

$\mathrm{X}_{5}$ is the number of mentions of the keyword "Ribera Market" in the descriptions of each host.

$\mathrm{X}_{6} \quad$ is the price of each accommodation.

$\mathrm{X}_{7} \quad$ is a dummy variable, which is 1 if it is situated in the old part of the city; otherwise it is 0 .

$\varepsilon_{\mathrm{i}} \quad$ is a random disturbance. 


\section{Results}

5.1. Descriptive Analysis of the Distance between Airbnb Accommodations by a Cluster Method in the City of Bilbao

Taking the geolocation of the accommodation, and in order to delve further into this issue, the DBSCAN, Density-Based Spatial Clustering of Applications with Noise, algorithm was used, with the implementation of a library [67], with the following parameters: maximum distance $=0.09 \mathrm{~km}$, and a minimum quantity of points $=5$.

As can be seen in Figure 4, the zero point was drawn where there was a greater concentration of Airbnb accommodations, specifically between the neighborhoods of Bilbao La Vieja (pink), San Francisco (green), and Casco Viejo/Old Town (blue).

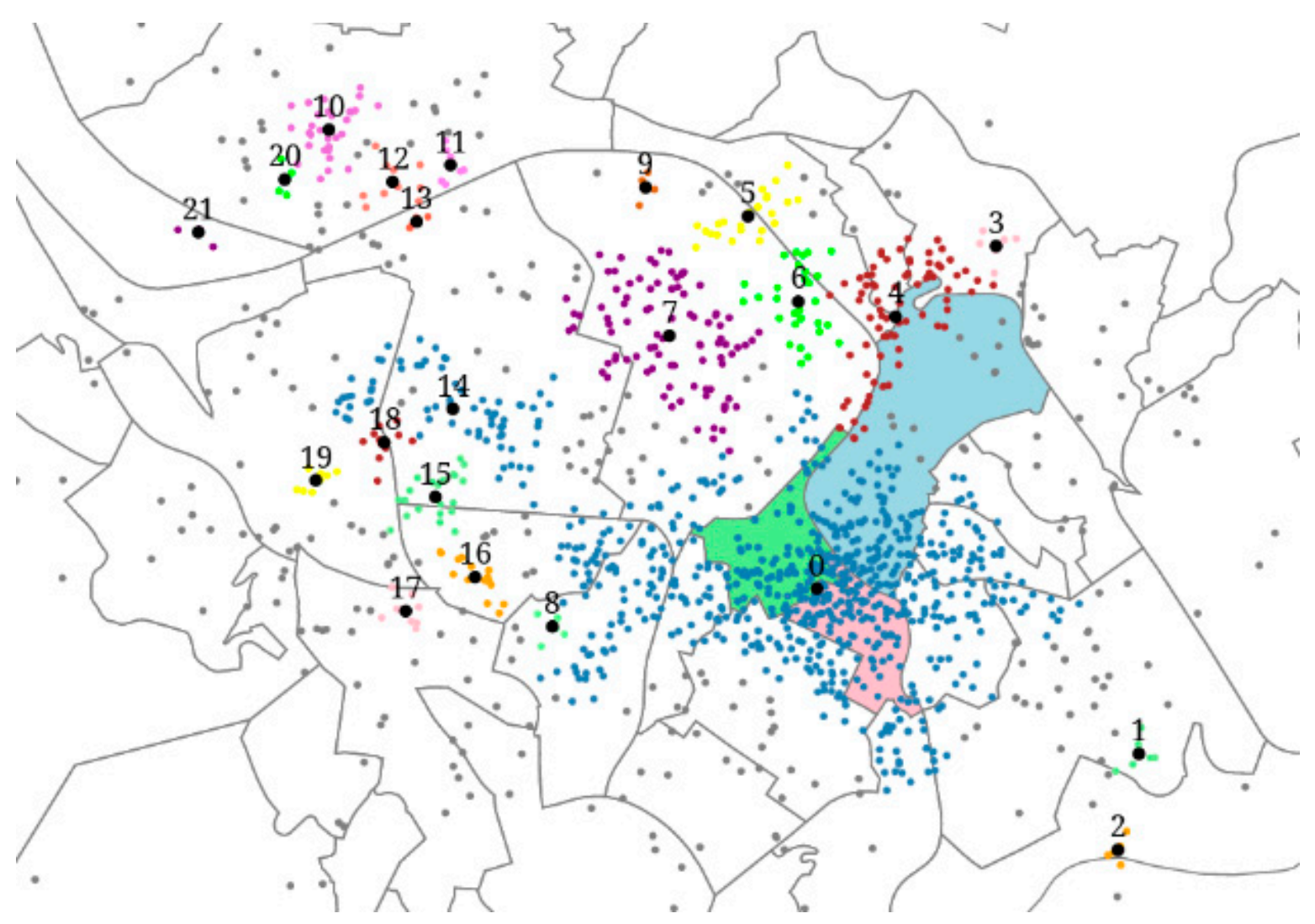

Figure 4. Concentration of Airbnb accommodation in the city of Bilbao, divided by the twenty-two clusters, and their differences by a cluster distance (Source: own elaboration).

\subsection{ANOVA}

In Tables 2 and 3, it can be seen that the location generated significant differences over the number of reviews. Thus, the accommodations located in the Old Town had a lower number of reviews, when compared to those not located in the Old Town.

Table 2. ANOVA analysis.

\begin{tabular}{cccccc}
\hline & Sum of Squares & df & Mean Square & F & Sig. \\
\hline Between & $36,743.994$ & 1 & $36,743.994$ & 12.728 & 0.000 \\
Groups & $909,371.703$ & 315 & 2886.894 & & \\
Within Groups & $946,115.697$ & 316 & & & \\
Total & & & & \\
\hline
\end{tabular}


Table 3. Levene's Test.

\begin{tabular}{cccc}
\hline Levene Statistic & gl1 & g12 & Sig. \\
\hline 24,679 & 1 & 315 & 0.000 \\
\hline
\end{tabular}

\subsection{Econometric Model 1}

In Table 4, the results showed the significance of the mentions of the heritage keywords, at a 10\% significance level and zipcode, at the 1\% significance level. On the other hand, the price variable was not significant, which indicated that it was not useful in discriminating the number of reviews. That is, an increase in the price of accommodation did not mean a decrease in the corresponding entries and overnight stays. Finally, the zipcode (a dummy variable indicating whether or not it was in the old part) was significant, which can mean that the heritage value of the old part was also significant when the guests chose a host.

Table 4. Ordinary least squares model from $1-326(n=318)$.

\begin{tabular}{ccccc}
\hline Variable & Coefficient & Standard Deviation & Statistic $t$ & $p$ Value \\
\hline Const & 34.6120 & 6.69721 & 5.168 & $<0.0001^{* * *}$ \\
Zipcode & 17.9852 & 6.38349 & 2.817 & $0.0051^{* * *}$ \\
Price & -0.0284673 & 0.0766502 & -0.3714 & 0.7106 \\
Heritage & 2.07936 & 1.14618 & 1.814 & $0.0706^{*}$ \\
\hline
\end{tabular}

Dependent variable: number_of_reviews; ${ }^{*} p<0.1$; $^{* *} p<0.05 ;{ }^{* * *} p<0.01$.

\subsection{Econometric Model 2}

Next, in Table 5, we verified that despite excluding the Guggenheim variable, which was probably the most famous patrimonial element, at an international level, which could bias the information of this sample, both the place of reference, the old part, and the cultural elements were still positively significant. In particular, the place (zipcode) was positively significant at $5 \%$ and the heritage variable was positive at the $10 \%$ significant level. That is, although hosts used the Guggenheim to sell the Bilbao brand on Airbnb, it did not mean that this museum had to be in the vicinity of the accommodation.

Table 5. Ordinary least squares model from $1-326(n=318)$.

\begin{tabular}{ccccc}
\hline Variable & Coefficient & Standard Deviation & Statistic $t$ & $p$ Value \\
\hline Const & 36.5609 & 6.49799 & 5.626 & $<0.0001^{* * *}$ \\
Heritage & 2.16271 & 1.27955 & 1.690 & $0.0920^{*}$ \\
Zipcode & 15.8118 & 7.19381 & 2.198 & $0.0287^{* *}$ \\
Price & -0.0216983 & 0.0770807 & -0.2815 & 0.7785 \\
\hline
\end{tabular}

Dependent variable: number_of_reviews; ${ }^{*} p<0.1 ;{ }^{* *} p<0.05 ;{ }^{* * *} p<0.01$.

\section{Discussion}

The objective of this work was to analyze how cultural heritage has an impact on the collaborative economy and how hosts use heritage as branding elements. In addition, the owners of accommodation listed on Airbnb sell their location and, indirectly, the city.

For this purpose, a methodology was proposed. This model was designed to take into account the supplier's point of view on Airbnb (most authors have analyzed the demand-side) and the description that the hosts use to list their residences to attract guests. For this reason, it was important to detect which keywords are used to attract tourists, and if they are related to the distinctive heritage elements of the city of Bilbao. Therefore, a series of permanent heritage elements in the city were considered (for this reason, circumstantial events were ignored) and their frequency of use in the hosts' descriptions were quantified. Moreover, other accommodation characteristics were collected such as the price of the accommodation and its location. 
Next, to evaluate the impact in the sharing economy of heritage branding, the number of reviews were estimated, based on several explanatory variables, such as location, price, and heritage mentions. Several authors [52] have used the accommodation attributes (location, price) as explanatory variables. However, the use of heritage mentions, as the explanatory variable, has been infrequent in the literature.

Regarding the use of the number of reviews as proxy of the number of bookings, some authors have found this proxy appropriate, at least as a relative value. For instance, the comparison made by Tom Slee [68] with published data from Berlin showed that these estimates were good enough. This means that the number of reviews was valid for estimating the trends or making comparisons of the bookings, similar to the Google Trends search index, when estimating the volume of searches.

\section{Conclusions}

The main conclusion of this paper was that the heritage branding made by hosts has a positive impact on the sharing economy and on tourism. In this way, the hosts become co-creators of the city branding.

This study addressed the crossover point between heritage tourism and the sharing economy, and focus was placed on the supplier side by analyzing the hosts' characteristics, given that most authors have analyzed the demand-side, by analyzing the guests' reviews and behavior. This research began from the mere observation of the evolution of tourism in the city of Bilbao. Thanks to a successful city branding strategy and differentiated tourism policy, Bilbao, like other post-Fordist metropolises, has adopted the service city model to move from an industrial one. Therefore, this approach presents many possibilities for new studies.

Another element to consider in this study was that of legislation, which is currently applying rules to this type of accommodation. Complete regulation has not yet been reached, but when that happens, it will further modify habits and their impact on traditional hotels, something that has already been and is currently being analyzed by other studies.

Additionally, this issue is closely linked to what is known as Gentrification 2.0. and, as in the case of cities affected by tourism in the USA (New Orleans, Los Angeles, and New York), Europe (Lisbon and London), or Spain (Barcelona, Madrid, and Palma de Mallorca), although to a much lesser extent, Bilbao has also suffered from neighborhood protests, due to the clustering of the center, as a globalized city that is not immune from the adverse effects of tourism. As seen in the last map, Bilbao is suffering, perhaps not from gentrification, like in other places with these phenomena in progress, but, at the very least, from what can be called Clusterization 2.0, of which the consequences are still unknown for the city of Bilbao.

Based on this paper, many future studies can be addressed. For instance, the methodology can be applied to other cities to check if the effects of heritage branding on collaborative tourism are maintained. Another interesting challenge would be to broaden the database, including every year since the existence of this platform, so that the patterns could be detected more accurately along with the consumer's quantitative consumption and its impact. Moreover, the events that take place in the city could also be studied as heritage elements and could be included in the model. Finally, it would be interesting to analyze the reasons why the hosts rent out their own homes, and whether it is a response to the need for living or is a pure business motivation. In other words, if there is a voluntary gentrification, it is thanks to Airbnb.

Author Contributions: All authors contributed equally to this work. All authors read and approved the final manuscript.

Funding: This research received no external funding.

Acknowledgments: The authors would like to thank Maria Pilar González and Beatriz Plaza, both from the Economic Applied Department in the University of the Basque Country, for their support in this investigation. We would like to thank Ekaitz Zarraga and Cristina Salmón for their help in the analyses.

Conflicts of Interest: The authors declare no conflict of interest. 


\section{References}

1. Richards, G. Cultural Tourism in Europe; Cab International: Wallingford, UK, 1996.

2. Hughes, H. Arts, Entertainment and Tourism; Routledge: Abington, UK, 2000.

3. Richards, G.; Wilson, J. Developing creativity in tourist experiences: A solution to the serial reproduction of culture? Tour. Manag. 2006, 27, 1209-1223. [CrossRef]

4. Richards, G. Creativity and tourism. Ann. Tour. Res. 2011, 38, 1225-1253. [CrossRef]

5. Kurin, R. Safeguarding Intangible Cultural Heritage in the 2003 UNESCO Convention: A critical appraisal. Mus. Int. 2004, 56, 66-77. [CrossRef]

6. Vecco, M. A definition of cultural heritage: From the tangible to the intangible. J. Cult. Herit. 2010, 11, 321-324. [CrossRef]

7. McGrath, J.M.; Primm, D.; Lafe, W. Heritage tourism's economic contribution: A Pennsylvania case study. Tour. Econ. 2017, 23, 1131-1137. [CrossRef]

8. Scott, A.J. The cultural economy of cities. Int. J. Urban Reg. Res. 1997, 21, 323-339. [CrossRef]

9. Throsby, D. Cultural capital. J. Cult. Econ. 1999, 23, 3-12. [CrossRef]

10. Bowitz, E.; Ibenholt, K. Economic impacts of cultural heritage-Research and perspectives. J. Cult. Herit. 2009, 10, 1-8. [CrossRef]

11. Capello, R.; Perucca, G. Cultural Capital and Local Development Nexus: Does the Local Environment Matter? In Socioeconomic Environmental Policies and Evaluations in Regional Science; Springer: Berlin/Heidelberg, Germany, 2017; pp. 103-124.

12. Sacco, P.; Ferilli, G.; Blessi, G.T. Understanding culture-led local development: A critique of alternative theoretical explanations. Urban Stud. 2014, 51, 2806-2821. [CrossRef]

13. Tweed, C.; Sutherland, M. Built cultural heritage and sustainable urban development. Landsc. Urban Plan. 2007, 83, 62-69. [CrossRef]

14. World Tourism Organization (WTO); European Travel Commission (ETC). City Tourism and Culture: The European Experience; World Tourism Organization (WTO): Madrid, Spain, 2005.

15. Aranburu, I.; Plaza, B.; Esteban, M. Sustainable Cultural Tourism in Urban Destinations: Does Space Matter? Sustainability 2016, 8, 699. [CrossRef]

16. Ashworth, G. The instruments of place branding: How is it done? Eur. Spat. Res. Policy 2009, 16, 9-22. [CrossRef]

17. Kavaratzis, M.; Ashworth, G.J. City branding: An effective assertion of identity or a transitory marketing trick? Tijdschr. Econ. Soc. Geogr. 2005, 96, 506-514. [CrossRef]

18. Plaza, B.; González-Casimiro, P.; Moral-Zuazo, P.; Waldron, C. Culture-led city brands as economic engines: Theory and empirics. Ann. Reg. Sci. 2015, 54, 179-196. [CrossRef]

19. Richards, G. Increasing the Attractiveness of Places Through Cultural Resources. Tour. Cult. Commun. 2010, 10,47-58. [CrossRef]

20. Tigre Moura, F.; Gnoth, J.; Deans, K.R. Localizing Cultural Values on Tourism Destination Websites: The Effects on Users' Willingness to Travel and Destination Image. J. Travel Res. 2015, 54, 528-542. [CrossRef]

21. Lacher, R.G.; Oh, C.-O.; Jodice, L.W.; Norman, W.C. The role of heritage and cultural elements in coastal tourism destination preferences: A choice modeling-Based analysis. J. Travel Res. 2013, 52, 534-546. [CrossRef]

22. Franco, S.F.; Macdonald, J.L. The effects of cultural heritage on residential property values: Evidence from Lisbon, Portugal. Reg. Sci. Urban Econ. 2018, 70, 35-56. [CrossRef]

23. Brandt, T.; Bendler, J.; Neumann, D. Social media analytics and value creation in urban smart tourism ecosystems. Inf. Manag. 2017, 54, 703-713. [CrossRef]

24. Marine-Roig, E.; Clavé, S.A. Tourism analytics with massive user-generated content: A case study of Barcelona. J. Destin. Mark. Manag. 2015, 4, 162-172. [CrossRef]

25. Xiang, Z.; Du, Q.; Ma, Y.; Fan, W. A comparative analysis of major online review platforms: Implications for social media analytics in hospitality and tourism. Tour. Manag. 2017, 58, 51-65. [CrossRef]

26. Marine-Roig, E. Measuring destination image through travel reviews in search engines. Sustainability 2017, 9, 1425. [CrossRef] 
27. Poulopoulos, V.; Vassilakis, C.; Wallace, M.; Antoniou, A.; Lepouras, G. The Effect of Social Media Trending Topics Related to Cultural Venues' Content. In Proceedings of the 13th International Workshop on Semantic and Social Media Adaptation and Personalization (SMAP), Zaragoza, Spain, 6-7 September 2018; pp. 7-12.

28. Casanovas, S. Del yo al Nosotros: Análisis y Diagnóstico de la Economía Colaborativa. Universitat Autònoma de Barcelona. Trabajo fin de Grado. 2014. Available online: https://ddd.uab.cat/record/126567?ln=en (accessed on 18 November 2017).

29. Guttentag, D. Airbnb: Disruptive innovation and the rise of an informal tourism accommodation sector. Curr. Issues Tour. 2015, 18, 1192-1217. [CrossRef]

30. Guttentag, D. Why Tourists Choose Airbnb: A Motivation-Based Segmentation Study Underpinned by Innovation Concepts. Ph.D. Thesis, University of Waterloo, Waterloo, ON, Canada, 2016.

31. Guttentag, D. Regulating innovation in the collaborative economy: An examination of Airbnb's early legal issues. In Collaborative Economy and Tourism: Perspectives, Politics, Policies and Prospects; Dredge, D., Gyimothy, S., Eds.; Springer: Cham, Switzerland, 2017; pp. 97-128.

32. Kaplan, R.A.; Nadler, M.L. Airbnb: A Case Study in occupancy regulation and taxation. Univ. Chic. Law Rev. 2015, 82, 103-115.

33. García-Hernández, M.; de la Calle-Vaquero, M.; Yubero, C. Cultural heritage and urban tourism: Historic city centres under pressure. Sustainability 2017, 9, 1346. [CrossRef]

34. Comiteau, L. Is Airbnb Making It Impossible to Find a House? Available online: http:/ /www.bbc.com/ capital/story / 20160811-is-airbnb-making-it-impossible-to-find-a-house (accessed on 16 August 2016).

35. Zervas, G.; Proserpio, D.; Byers, J. The Rise of the Sharing Economy: Estimating the Impact of Airbnb on the Hotel Industry. J. Mark. Res. 2017, 54, 687-705. [CrossRef]

36. Loannides, D.; Röslmaier, M.; van der Zee, E. Airbnb as an instigator of 'tourism bubble' expansion in Utrecht's Lombok neighbourhood. Tour. Geogr. 2018, 83, 1-19. [CrossRef]

37. Fierro, A.; Salmón, C. El Impacto del Turismo en el Casco Viejo de Bilbao Mediante los Modelos de Economía Colaborativa: Una Aproximación a Través de una Distribución Binomial Negativa. Lurralde Investig. Espac. 2017, 41, 175-201.

38. Kotler, P.; Haider, D.H.; Rein, I.R. Marketing Places: Attracting Investment, Industry and Tourism to Cities, States and Nations; Free Press/Macmillan: New York, NY, USA, 1993.

39. Hankinson, G. The management of destination brands: Five guiding principles based on recent developments in corporate branding theory. Brand Manag. 2006, 14, 240-254. [CrossRef]

40. Kotler, P.; Asplund, C.; Rein, I.; Heider, D. Marketing Places Europe: Attracting Investments, Industries, Residents and Visitors to European Cities, Communities, Regions and Nations; Pearson Education: London, UK, 1999.

41. Riza, M.; Doratli, N.; Fasli, M. City Branding and Identity. Procedia-Soc. Behav. Sci. 2012, 35, $293-300$. [CrossRef]

42. Hankinson, G. Relational network brands: Towards a conceptual model of place brands. J. Vacat. Mark. 2004, 10, 109-121. [CrossRef]

43. Kavaratzis, M. Branding the city through Culture and Entertainment. J. AESOP 2005, 5, 1-7.

44. Szondi, G. Public Diplomacy and nation Branding: Conceptual similarities and differences. Place Brand. Public Dipl. 2007, 3, 8-20. [CrossRef]

45. Florek, M.; Conejo, F. Export flagships in branding small developing countries: The cases of Costa Rica and Moldova. Place Brand. Public Dipl. 2007, 3, 53-72. [CrossRef]

46. Kemming, J.D.; Özlem, S. Turkey's EU Accession as a Question of Nation Brand Image. Place Brand. Public Dipl. 2007, 3, 31-41. [CrossRef]

47. Gilmore, F.J. A country-Can it be repositioned? Spain-The success story of country branding. J. Brand Manag. 2002, 9, 281-293. [CrossRef]

48. Botsman, R.; Rogers, R. What's Mine Is Yours: The Rise of Collaborative Consumption; Harper Collins E-Books: New York, NY, USA, 2010.

49. Schor, J.B.; Fitzmaurice, C.J. 26. Collaborating and connecting: The emergence of the sharing economy. In Handbook of Research on Sustainable Consumption; Edward Elgar Publishing: Dortmund, UK, 2015; p. 410.

50. Hu, N.; Zhang, J.; Pavlou, P.A. Overcoming the J-shaped distribution of product reviews. Commun. ACM 2009, 52, 144-147. [CrossRef] 
51. Georgios, Z.; Davide, P.; John, B. A First Look at Online Reputation on Airbnb, Where Every Stay is Above Average (28 January 2015). Available online: http:/ / dx.doi.org/10.2139/ssrn.2554500 (accessed on 15 October 2018).

52. Wu, J.; Ma, P.; Xie, K.L. In sharing economy we trust: The effects of host attributes on short-term rental purchases. Int. J. Contemp. Hosp. Manag. 2017, 29, 2962-2976. [CrossRef]

53. Ert, E.; Fleischer, A.; Magen, N. Trust and reputation in the sharing economy: The role of personal photos in Airbnb. Tour. Manag. 2016, 55, 62-73. [CrossRef]

54. Lalicic, L.; Weismayer, C. The role of authenticity in Airbnb experiences. In Information and Communication Technologies in Tourism; Springer: Berlin/Heidelberg, Germany, 2017; pp. 781-794.

55. Kolar, T.; Zabkar, V. A consumer-based model of authenticity: An oxymoron or the foundation of cultural heritage marketing? Tour. Manag. 2010, 31, 652-664. [CrossRef]

56. The National Commission on Markets and Competition. Available online: https://www.cnmc.es/ (accessed on 11 February 2017).

57. Eustat. The Statistical Office of the Basque Country. Available online: http://www.eustat.eus (accessed on 10 December 2018).

58. Airbnb Global Trends. 2017. Available online: https:/ / press.airbnb.com/the-u-s-midwest-ryokans-andbrazilian-beaches-airbnbs-2018-travel-trends / (accessed on 12 May 2018).

59. Haarich, S.; Plaza, B. The Guggenheim Museum in Bilbao-At the Centre of a Creative City. Urban Plan. Int. 2012, 27, 11-16.

60. González-Pulido, F.; Vaggione, P.; Ackley, L.A. The Genesis of the Guggenheim Bilbao Museoa Center for Design Informatics; Harvard Design School: Boston, MA, USA, 2002.

61. Plaza, B. A note on "Panorama of the Basque Country and its competence for self-government: Terrorism and the Guggenheim Museum Bilbao effect. Eur. Plan. Stud. 2002, 10, 383-389. [CrossRef]

62. Plaza, B.; Tironi, M.; Haarich, S. Bilbao's Art Scene and the "Guggenheim effect" Revisited. Eur. Plan. Stud. 2009, 17, 1711-1729. [CrossRef]

63. Tussyadiah, I.P. Factors of satisfaction and intention to use p2p accommodation. Int. J. Hosp. Manag. 2016, 55, 70-80. [CrossRef]

64. Mittendorf, C. What Trust Means in the Sharing Economy: A provider perspective on Airbnb.com. In Proceedings of the AMCIS, San Diego, CA, USA, 11-14 August 2016.

65. Montera 34. Available online: https://montera34.com/en (accessed on 21 April 2017).

66. Gujarati, D.N.; Porter, D.C. Basic Econometrics, 5th ed.; McGraw-Hill: New York, NY, USA, 2009.

67. DBSCAN Cluster Library. Available online: https://scikit-learn.org/stable/modules/generated/sklearn. cluster.DBSCAN.html (accessed on 29 September 2017).

68. Slee, T. What's Yours Is Mine: Against the Sharing Economy; Or Books: New York, NY, USA, 2017. 